\title{
BELONGINGNESS TO CANADA: \\ SYNTHESIZING CANADIANNESS AND MUSLIMNESS AMONG NEWLY EMERGENT CANADIAN MUSLIMS
}

\author{
Muhammad Izzul Haq \\ McGill University, Montreal, Canada \\ E-mail: muhammad.haq@mail.mcgill.ca
}

\begin{abstract}
The recent statistic reveals the number of Canadian Muslims increases multifold in decades. It is predicted that the Canadian Muslim population will grow significantly. The demographic postures of varied Canadian Muslims offer several features requiring scholarly attention and action from all interested stakeholders to look into the situation. That is to evoke Canadianness among those newly emergent Canadian Muslims who came to Canada as immigrants or born here and grown-up as Muslim. When each boundary is negotiated, the spectrum of Muslimness and Canadianness is synthesized in the making. This ongoing situation demands particular action to nurture a sense of belongingness for newly emergent Canadian Muslims to protect and promote Canadian multicultural society amidst external and internal challenges such as Islamophobia and radicalism. Based on scoping reviews on selected pieces of literature, the idea of finding a new model or denomination of Islam in Canada is a convincing step to synthesize Canadianness and Muslimness, which reflect the empirical situation of newly emergent Muslims in Canada. The history of the first mosque built in Canada taught us how the synthesis can be practically applied, how flexible Islam can be genuinely promoted, and the lines of doctrine and cultural difference can be deliberately blurred. This ethos demonstrates compatibility with Canadian values of openness and respect to diversity.
\end{abstract}

Keywords: Canadianness; Muslimness; belongingness. 


\section{Introduction}

Recent decades demonstrate the growth of Muslim population in Canada. According to the 2011 National Household Survey, 7\% of the total Greater Toronto Area are Muslims who come from Pakistani, Bangladeshi, Indian, Iranian and Egyptian/Arab descent. While $6 \%$ of Greater Montreal Muslim community are from Western/Southern Europe, Caribbean, North Africa, the Middle East, and the Indian subcontinent. Meanwhile, Ottawa as national capital that has 5.5\% Muslim community hosts many Lebanese, South Asian and Somali Muslims, in general almost every Muslim country in the world has sent immigrants to Canada-from Albania, Bosnia Herzegovina to Yemen, from Syria, Iran to Bangladesh. ${ }^{1}$ However, it is also followed by sparking tension and challenges. Several instances of Islamophobia have been experienced by Muslims in Canada. ${ }^{2}$ There is a considerable report on the rise of Islamophobia in Canada ${ }^{3}$ even during COVID-19 crise; ${ }^{4}$ meanwhile, radicalism among Muslim also exist in Canada, ${ }^{5}$ and mainly Muslim youth are vulnerable to radicalization. ${ }^{6}$ These common features set a backdrop of situating Islam in the contemporary Canadian mosaic of multiculturalism.

1 Statistics Canada, "2011 National Household Survey Profile-Census Metropolitan Area/Census Agglomeration," May 8, 2011, available at $<$ https://www12.statcan.gc.ca/nhs-enm/2011/dppd/prof/details/page.cfm?La ng $=\mathrm{E} \& \mathrm{Geo} 1=\mathrm{CMA} \&$ Code $1=462 \&$ Data $=$ Count $\&$ SearchText $=$ montreal $\&$ Searc $\underline{\mathrm{h} T y p e}=$ Begins $\&$ SearchPR $=01 \& A 1=$ Religion $\& B 1=$ All $\&$ Custom $=\& T A B I D=1>$ 2 G.M.D. Erin, "Muslims in Canada: Collective Identities, Attitudes of Otherment and Canadian Muslim Perspectives on Radicalism," Islamophobia Studies Journal, Vol. 3, No. 1 (2015), 44.

3 CJPME, "2018 Survey: Islamophobia in Canada, Still A Grace Problem,” 2018, available at <https://www.cipme.org/islamophobia $>$; Azeezah Kanji, "Islamophobia in Canada: Submission to the UN Special Rapporteur on Freedom of Religion or Belief," November 30, 2020, available at $<$ https://www.ohchr.org/Documents/Issues/Religion/Islamophobia-AntiMus

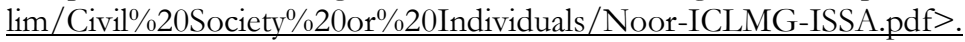

${ }^{4}$ Khaled Al-Qazzaz, "Islamophobia Is on the Rise during COVID-19," Policy Options (October 2020), availabe at < https://policyoptions.irpp.org/magazines/ october-2020/islamophobia-is-on-the-rise-during-covid-19/>.

5 Ahmed Kawser, "Radicalism Leading to Violent Extremism in Canada: A Multilevel Analysis of Muslim Community and University Based Student Leaders' Perceptions and Experiences," Journal for Deradicalization, No. 6 (2016), 231-271.

${ }^{6}$ Erin, "Muslims in Canada." 
Canada is still leading and presiding multiculturalism. However, only Quebec display resistance as a way to protect French culture that prefers to embrace interculturalism instead of multiculturalism. ${ }^{7}$ As one dimension of multiculturalism, integration becomes crucial. ${ }^{8}$ The idea of synthesizing Canadianness and Muslimness comes from the need to converge the values that may conflate during its interaction. This idea also answers the question to what extent Islamic values are compatible with Canadian values. While some argue that Islam is compatible with Canada, some others have reservations on what type of Islam can adapt to Canadian society.

In this case, it would be not exaggerated to propose that some portion of Islamic values would be instilled or embedded within Canadian values, or least to say, Islamic values will contribute to filling the mosaic of Canadian values, together with other values.

Given its extensive coverage across the globe, it must be wellnoted that Islam is not a monolithic religion. Islam is a diverse religion that many contexts have influenced, be it historical or political landscape throughout centuries. There are so vastly different denominations, articulation, and expression of Islam. To view Islam from a single optic will create dangerous understanding given so many differences within Islam. Hitherto, the ways Islam is articulated or expressed as a quality of Muslimness are undoubtedly varied.

This article seeks to start a conversation on how belongingness to Canada can be promoted among newly emergent Muslims. Several questions are raised: what and how synthesizing values of Canadianness and Muslimness can be applied? Who and how can the synthesis be done?

\footnotetext{
7 Isabel Wences, "Quebec Interculturalism: A Version of Canadian Multiculturalism or a Model with an Institutional Structure?," Convergencia, Vol. 23, No. 72 (2016), 115-141.

${ }^{8}$ Michael Clyne and James Jupp, Multiculturalism and Integration (N.p.: ANU Press, 2011), available at $<$ http://www.jstor.org/stable/j.ctt24h7j6> accessed on May 6, 2021; Patricia L. Nemetz and Sandra L. Christensen, "The Challenge of Cultural Diversity: Harnessing a Diversity of Views to Understand Multiculturalism," The Academy of Management Review, Vol. 21, No. 2 (April, 1996), 434.
} 


\section{Scoping Review on Studies and Reports on Muslim and Canada}

Some scholars have noted the interrelation of the Muslimness of a Muslim is heavily influenced by cultural background. Therefore, it is a quest to look into how cultural synthesis between Canadian values and Islamic values could also be implemented. The idea of finding and establishing Islamic practice rooted in Canadian culture based on Canadian values will affirm this synthesis.

To find the conclusive finding, I will do scoping review as "exploratory projects that systematically map the literature available on a topic, identifying key concepts, theories, sources of evidence and gaps in the research." Although the definition and process of scoping review are evolving, ${ }^{10} \mathrm{I}$ would look carefully into some findings from articles and reports aforementioned or narrate about Muslims or Islam in Canada. Two main search processes (i.e. structured and unstructured) were followed by compiling both academic and grey literature from different databases.

The second strand of literature (unstructured) search involved an exhaustive process of backward and forward searches ${ }^{11}$ on articles included and generated from the initial (structured) search process. This search comprised two steps. First, reviewing a selection of older literature cited in the articles generated during the initial keyword search and additional sources that also cite the selected theme. The second step encompassed a targeted search of grey literature databases, including Google Scholar. The resources from this search included reports as well as statistics. Wohlin ${ }^{12}$

\footnotetext{
9 Kelly K. O’Brien et al., “Advancing Scoping Study Methodology: A WebBased Survey and Consultation of Perceptions on Terminology, Definition and Methodological Steps," BMC Health Services Research, Vol. 16, No. 1 (December, 2016), 305.

${ }^{10}$ Jessica Peterson et al., "Understanding Scoping Reviews: Definition, Purpose, and Process," Journal of the American Association of Nurse Practitioners, Vol. 29, No. 1 (January, 2017), 12-16.

${ }^{11}$ C. Wohlin, "Guidelines for Snowballing in Systematic Literature Studies and a Replication in Software Engineering," in Proceedings of the 18th International Conference on Evaluation and Assessment in Software Engineering, Vol. 38 (Citeseer, 2014).

12 Ibid.
} 
further asserted that one of the main advantages of snowballing is that it starts from relevant papers, and then these studies can drive further research. Reference lists are quite easily examined, and when combined with the place and context of the reference, it becomes pretty straightforward to identify relevant papers in most cases.

Some studies have recently paid a great deal of scholarly attention to the growth of Muslim communities in Canada. Some projects also produce informative displays of Islam in Canada, such as documentary series and media project of A New Life in a New Land, ${ }^{13}$ which provides current information on Islam and Muslims in Canada accurately. A New Life in a New Land follows the spirit of Canada's inclusive, multicultural policy. It breaks down barriers and eliminates negative stereotypes that fuel racism and discrimination.

There are two recent reports about Islam in Canada that portray how Muslim presence in Canada ${ }^{14}$ that I will use as an informative source for further analysis and discussion.

\section{On Belongingness, Attachment Towards Integration}

As part of preserving and promoting multiculturalism as a Canadian national project, the idea of integration still occupies a common mindset. A key to integrating is to have an attachment, and a sense of belonging becomes a crucial element in nurturing bonding attachment. Belongingness is such an essential human motivation that we feel severe consequences for not belonging. ${ }^{15}$ Were it not so fundamental, then the absence of a sense of belonging would not have such severe consequences for

\footnotetext{
${ }^{13}$ Flordeliza Dayrit and Michael Milo, "A New Life in a New Land: The Muslim Experience in Canada," 2015, available at < $\underline{\text { https://www.anewlife.ca/ } />\text {. }}$

14 Environics Institute, "Survey of Muslims in Canada 2016: Final Report," April 30, 2016, available at <http://www.environicsinstitute.org/uploads/instituteprojects $/$ survey $\% 20$ of $\% 20$ muslims $\% 20$ in $\% 20$ canada $\% 202016 \% 20-\% 20$ final $\% 2$ Oreport.pdf $>$; Daood Hamdani, "Canadian Muslims: A Statistical Review" (The Canadian Dawn Foundation, 2015), available at <https://muslimlink.ca/ pdf/Canadian-Muslims-A-Statistical-Review-Final.pdf $>$.

15 Roy F. Baumeister and Mark R. Leary, "The Need to Belong: Desire for Interpersonal Attachments as a Fundamental Human Motivation," Psychological Bulletin, Vol. 117, No. 3 (1995), 499.
} 
us. This need is so universal and found across all cultures and different types of people.

Similarly, belonging is a strong and inevitable feeling in human nature and a major source of human motivation. ${ }^{16}$ It is a subjective experience that a number of factors within ourselves and our surrounding environment influence to belong or not to belong. ${ }^{17}$

Along with other needs such as physiological needs, safety, self-esteem, and self-actualization, Maslow ${ }^{18}$ thought that belonging was one of five human needs in his hierarchy of needs. An individual can meet the need to belong and be loved after physiological and safety requirements are met. Maslow emphasized that if the first two needs are not met, an individual cannot completely love someone else.

To get along with others and gain acceptance into social groups is what humans profoundly need. When relationships weaken, or social bonds are broken, people have been found to suffer from depressive symptoms. Those who are depressed are more vulnerable to negative experiences of belonging. Due to the importance of social experiences to people's well-being and the maintenance of depression, it is vital to examine how positive and negative social interactions enhance or erode well-being. ${ }^{19}$

Belongingness or connectedness has been recognized as a high risk or predictive factor for depressive symptoms. There is growing evidence that depressive symptoms are strongly associated with the interpersonal aspect of belongingness. Low relational value is consciously experienced as reduced self-esteem, which is a fundamental element of depressive symptoms. Based on these views, belongingness perceptions directly affect depressive symptoms due to innate neurological mechanisms. ${ }^{20}$

\footnotetext{
16 Abraham H. Maslow, Toward a Psychology of Being, Second Edition (New York: D. Van Nostrand Company, 1968), 45.

17 Kelly-Ann Allen, The Psychology of Belonging, First Edition (N.p.: Routledge, 2020), 5.

18 Maslow, Toward a Psychology of Being.

${ }_{19}$ Michael F. Steger and Todd B. Kashdan, "Depression and Everyday Social Activity, Belonging, and Well-Being," Journal of Counseling Psychology, Vol. 56, No. 2 (2009), 289-300.

20 Wendell David Cockshaw and Ian Shochet, "The Link between Belongingness and Depressive Symptoms: An Exploration in the Workplace
} 


\section{On Canadianness, the Continual Growth of National Character}

What is Canadianness? According to Magocsi, ${ }^{21}$ Canadianness refers to the state or quality of being Canadian. Yet, what is a Canadian? This short question could face innumerable answers and might show paradoxical points of view as $\operatorname{Studin}^{22}$ sets out to approach prominent Canadians, and 43 thought-provoking responses are generated. However, the issue will emerge since the Canadian population is constantly emerging. Hence, the flow of immigrants and the growth of the young generation. Some scholars have pointed out the potential threat of diminishing Canadian values against any culture deemed incompatible or irrelevant with Canadian values.

However, a critical question can be asked. What are Canadian values? Historically, it could be argued that the very foundation of modern Canada rests on a terrible ambiguity that rests upon difference among two founding nations. For most Englishspeaking Canadian leaders in 1867, a new nation was created by the British North America Act. On the other hand, for French Canadians, however, the new country resulted from a contract between provinces, especially between the French-speaking province of Quebec, which received unique guarantees of autonomy, and the other English-speaking components of Canada. ${ }^{23}$ This different mindset has virtually acknowledged the creation of Canada is always mingled with different values. Canadianness is an amalgam of culture among nations, created from multiple layers of values generated from the interaction of First Nations, the development of two founding nations (early English and French settlers) and the wave of immigrants' population from around the world.

Interpersonal Context," Australian Psychologist, Vol. 45, No. 4 (December, 2010), 283-289.

21 Paul R. Magocsi (ed.), Encyclopedia of Canada's Peoples (Toronto; Buffalo: University of Toronto Press, 1999).

22 Irvin Studin, "What Is a Canadian?: Forty-Three Thought-Provoking Responses" (Toronto: M \& S, 2006), available at < $\underline{\text { http://catdir.loc.gov/ }}$ catdir/enhancements/fy0624/2006494464-s.html>.

${ }^{23}$ Leen D'Haenens, Images of Canadianness: Visions on Canada's Politics, Culture, and Economics (N.p.: University of Ottawa Press, 1998), 36. 
Hence, finding common values that characterize Canadianness must be thoroughly added into our consciousness and continually become part of a national quest. Some scholars agree that openness, respect for human rights, diversity are some values that most Canadians respect. The way Canada has played in the international sphere emphasizes those values. These values also explain how Canada has tried to set up stark differences with the neighbouring southern state, the U.S., which solidifies the embodiment of Canadian values.

In an essay on Canadian culture and how it differs from being American, Kymlicka ${ }^{24}$ observes that Canadianness is quite morally equivalent to Americanness. He keeps that Canadians are still looking for ways to distinguish themselves from Americans. Despite the similarities between the two identities, he insists that being Canadian is defined above all by not being an American. Kymlicka also notes that Canadian identity is continually renegotiated about internal sub-group identities such as Québécois, Indigenous or immigrant groups, and these external international or transnational identities.

\section{On Muslimness, Unpacking Contested Concept}

Some scholars ${ }^{25}$ have discussed Muslimness. However, there is no single agreed conception of Muslimness found in their works. For instance, Sulaiman ${ }^{26}$ renounces objectivity, which fixes,

\footnotetext{
24 Will Kymlicka, "Being Canadian," Government and Opposition, Vol. 38, No. 3 (2003), 357-385.

25 Reihaneh Haghbin, "The Problem of Muslimness: Reconsidering the Theology of Inclusion-Exclusion in Muslim Thought" (N.p.: Middlesex University, 2016), available at <https://www.islamic-college.ac.uk/wpcontent/uploads/2018/10/Reihaneh-HAGHBIN-Dissertation-final.pdf $>$;

Anissa Helie, "Introduction: Policing Gender, Sexuality and 'Muslimness," in Sexuality in Muslim Contexts-Restrictions and Resistance (N.p.: Zed Books, 2012), 215; Amina Alrasheed Nayel, Alternative Performativity of Muslimness (Cham: Springer International Publishing, 2017), available at <http:// link.springer.com/10.1007/978-3-319-44051-4> accessed on April 16, 2021; Jennifer A. Selby, "Muslimness" and Multiplicity in Qualitative Research and in Government Reports in Canada," Critical Research on Religion, Vol. 4, No. 1 (April 2016), 72-89; Mohammed Sulaiman, "Muslimness as a Political Formation: An Inquiry into Muslim Presence," Social Identities, Vol. 26, No. 1 (January, 2020), 31-47.

${ }^{26}$ Sulaiman, "Muslimness as a Political Formation."
} 
essentializes, and reduces. Muslimness is no merely 'religious' as opposed to 'political.' Instead, he emphasizes the importance of Muslimness as a political subjectivity, which the mechanism of the caliphate had historically fulfilled.

Similarly, Muslimness is referred to as the idea of 'Muslim world,' which is by no means the monolithic whole suggested by some scholars. However, as Helie criticizes, ${ }^{27}$ this tendency tends to hide the complex historical, cultural, economic and political legacies that influence specific Muslim societies. The idea of a 'Muslim world' also overlooks the variety of meanings attached to 'Islam' between different cultures, with individuals or groups adopting different beliefs and practices. In a similar tone, the concept of 'Muslimness' under the above interpretation will inaccurately imply a homogenous understanding of Islam. Far from being designed to go beyond existing differences, the discourse of 'Muslimness' will purposely ignore diversities that live and operate across and within Muslim communities and projects a diasporic identity centred on an imaginary transnational Muslim culture. $^{.28}$

Meanwhile, Haghbin ${ }^{29}$ looks from a different lens and emphasizes how the problem of "Muslimness" is one of the most critical issues in the history of Muslim thought since it influenced the perspective on the Muslims and brought segregation and various guidelines for each Islamic group. Muslimness here meant the quality of practicing Islam and being Muslim. In such manner, Islamic organizations save the intrinsic prevalence for their devotees and mediocrity for different gatherings. They thereby give less significance to another denomination that does not think or act based on their criteria and even exclude other Muslim opponents from the community of Islam.

One of the robust solutions proposed by Haghbin ${ }^{30}$ to cope with the problem of Muslimness is to present the new interpretation of the Qur'ān and to issue some new legal theories

\footnotetext{
${ }^{27}$ Helie, "Introduction."

28 M. Hélie-Lucas, "What Is Your Tribe? Women's Struggles and the Construction of Muslimness," in Annisa Helie and Homa Hoodfar (eds.), Women Living Under Muslim Laws (London; New York: Zed Books, 2004), 1-14.

${ }^{29}$ Haghbin, "The Problem of Muslimness," 9.

${ }^{30}$ Ibid., 28.
} 
based on the moral values governing the spirit of the Qur'ān. This interpretation is the critical task and responsibility of jurists and religious scholars ('ulam $\bar{a}$ ' and fuqaha $\bar{a}$ ) and theologians and religious intellectuals to produce some provisions and conditions to the law of apostasy, indicating the leave of someone from the guidance of Islam.

Further, Haghbin ${ }^{31}$ stated that every person should be free to investigate Islam even if the consequence of this research would become the conversion from Islam. We have to consider Islam as a process-oriented (existential) rather than a product-oriented (fixed) religion. It means that Islam is constantly dealing with on going process of both acceptance and rejection among people. In this regard, it is only upon God to distinguish the rightness of faith from unauthentic faith and to judge about the faith and deeds of individuals

The understandings of Muslimness are complicated further if one considers the issue of performativity as explored by $\mathrm{Nayel}^{32}$ who emphasizes the cultural background. As she underlined, those who have come from an African Islamic culture will experience and perform their Muslimness from within that culture. This performance is achieved through the intersection of Islam and African traditional beliefs, manifested in how they read, understand, interpret and perform the religion of Islam. There is a clear-cut distinction between Muslims from Asian countries and Muslims from African and Middle Eastern countries. Their position dismisses the notion of one authentic Islamic identity. Taking Britain as an example, 'the Muslims' in Britain is a category that usually refers to the mainstream Islam associated with the Asian Muslim communities in the U.K. since the majority of Muslims in the U.K. are from Asian countries, such as Pakistan, India and Bangladesh. They have shaped mainstream Islam in the U.K., and thanks to their numbers, they have dominated and assumed the role of representing 'the Muslim community' in the U.K.

Selby ${ }^{33}$ defines Muslimness as the essential qualities presumed to be shared by Muslims negotiated in a minority context. Further,

\footnotetext{
31 Ibid., 37.

${ }^{32}$ Nayel, Alternative Performativity, 9.

${ }^{33}$ Selby, “"Muslimness' and Multiplicity," 83.
} 
she reiterates that like most things that are alive, Muslim expressions of religiosity are not monolithic but are messy, mundane, and multiple. Meanwhile, the concept of Muslimness is still contested since conservative forces and fundamentalist actors linked to the religious right in Muslim communities around the world rely on selective interpretations of Islam. By way of this, they oppose sexual diversity and gender equality and impose their radical agenda that inevitably violates human rights and promotes violence.

\section{Diversity of Muslim(ness) in Canada}

Muslim population is changing. After decades of slow change, a demographic transformation is underway. Canadian-born Muslims made up 22 percent of the Muslims in 1991. In the next ten years, this proportion increased slowly to 24 percent but jumped to 28 percent and reached a milestone in 2011. It passed the one million mark. In relative terms, Muslims are 3.2 percent of the total Canadian population and rank fifth among faith communities and denominations. They are an urban community, with two-thirds living in just two cities, Toronto and Montreal. Canadian Muslims are a mix of newcomers and descendants of families that settled here more than a century ago. Canadian-born Muslims have already surpassed the Arab Muslim population and are now poised to replace the South Asians as the largest group. ${ }^{34}$

The emerging generation is less fixated on ethnicities than their parents or grandparents. Born into diverse ethnicities but bound by their Canadian heritage and shared faith, they come closest to defining that cherished but elusive entity called 'ummah.' The term 'ummah' refers to what Houtsma ${ }^{35}$ refers typically to a single group that shares common religious beliefs, specifically those that are the objects of a divine plan of salvation through Islam. Visionary leadership can seize the moment to develop a Canadian Muslim identity and set an example for Muslims in other Western societies. Only a few generations are privileged to have such an opportunity. ${ }^{36}$

\footnotetext{
${ }^{34}$ Hamdani, "Canadian Muslims."

${ }^{35}$ M. Th Houtsma (ed.), E.J. Brill's First Encyclopaedia of Islam, 1913-1936 (Leiden; New York: E.J. Brill, 1987).

${ }^{36}$ Hamdani, "Canadian Muslims."
} 
Indeed, Canada is the showcase of Islam's plurality in its cultural, linguistic, and ethnic diversity. Yet, Muslims are one of the most misunderstood faith communities in the country and the subject of misinformation and misperceptions. ${ }^{37}$

A majority of Canada's Muslim population follows Sunni Islam, while a significant minority adhere to the Shia (either Twelvers or Ismaili) and Ahmadiyya branches. ${ }^{38}$ Canadian Muslims comprise more than five dozen different ethnic groups with origins in Asia, Africa, America, Europe and Oceania. Although ethnic origin is a key characteristic of a pluralist society, classifying the population is becoming difficult as more and more people are intermarrying. An increase in the number of children born of mixed marriages raises classification issues and questions about its usefulness for studying integration. Four in ten (43 percent) Canadians report multiple ethnicities. ${ }^{39}$

Islam as a multifaceted religion is echoed in Azmah's words, 'there are as many Islam parties in Islam as there are situations that sustain it. ${ }^{40}$ Muslims are well respected. Who does not acknowledge Islamic tradition, nor do they abide by it, but they perceive themselves as Muslims. It is the same with Christianity. There are many varieties and sects. Therefore, Muslimness is fluid, multidimensional and multifaceted identities, not homogenous.

To be Muslim is to ascribe to Muslim culture and community and perform Muslimness within specific boundaries, as is mainstream Islam in Canada, performed by most immigrant Muslims from different ethnicities. The intersection between ethnicities and religious identities cannot be oversimplified, as different Islamic identities relate in various ways to ethnic issues.

Further precaution must be reserved for adopting concepts of authentic Muslimness since it will marginalize outcast Muslims in the Muslim community, where they are stigmatized due to their difference in appearance, dress code, and skin colour. Stigmatization, which cuts across culture, religion, ethnicity, and

\footnotetext{
${ }^{37}$ Ibid., 1.

${ }^{38}$ Michael Adams, "Muslims and Multiculturalism in Canada," 2007, available at $<\underline{\text { http://www.environicsinstitute.org/PDF-MuslimsandMulticulturalisminCana }}$ da-LiftingtheVeil.pdf $>$.

${ }^{39}$ Hamdani, "Canadian Muslims," 10.

${ }^{40}$ Houtsma (ed.), E.J. Brill's First Encyclopaedia.
} 
race, does not acknowledge Muslim differences and mainstream Islam in Canada against Canadian values and distorts Canadianness. The interpretations of the religious text differ widely, and so do the practices, understanding and performances which pertain to Muslimness. Indeed, an ethnic dimension appears when the subjects are both Muslim and Canadian

Kahani-Hopkins and Hopkins ${ }^{41}$ show how the collective identification of Muslimness within British society is constructed. The large majority of Muslims from Asia and the minority Muslim groups from Africa or the Middle East, all unable to establish one harmonized group of Muslims. This situation can also apply to Muslim groups in Canada.

\section{Belongingness of Muslim to Canada}

Based on the latest survey by Environics Institute, ${ }^{42}$ immigrants to Canada are among the most loyal and proud citizens. This survey also applies to Muslims, with more than eighty percent saying they are very proud to be Canadian. This extent has expanded by ten rate focuses since a decade before. Although this upward trend in great pride is evident across most Muslim communities, the most significant is in Quebec (where it has jumped 30 percentage points, to $77 \%$ ).

The survey also explored what gives Muslims the most considerable pride in their country, mainly similar qualities distinguished by different Canadians (as recorded in past Center Canada overviews). These are Canadian values that offer a rich source of Canadianness attributes. On top of the list are Canada's freedom and democracy (24\%), its diversity and multiculturalism $(22 \%)$, Canada's reputation as being a peaceful and stable country, followed by its humanitarian people, lower crime rate, more tolerance and respect for others, and its laws guaranteeing equality and human rights. ${ }^{43}$

The 2016 survey also asked a related question about people's sense of belongingness to Canada, reflecting how one feels

\footnotetext{
41 Vered Kahani-Hopkins and Nick Hopkins, "Representing' British Muslims: The Strategic Dimension to Identity Construction," Ethnic and Racial Studies, Vol. 25, No. 2 (January, 2002), 288-309.

42 Environics Institute, "Survey of Muslims."

${ }^{43}$ Ibid.
} 
acknowledged by the wider society. Almost all Muslims participating in the study feel a sense of belonging to Canada, with over half $(55 \%)$ saying they have very strong belongingness. The rest $(39 \%)$ signalling it is mostly strong. This very strong belongingness is most prevalent in western Canada, among Muslim men 60 years and older, immigrants who have lived in the country for two decades or more years, and those who primarily identify as Canadian (versus identifying primarily as a Muslim). This view is least evident among women (45\%) and Muslims aged 18 to 34 (41\%). Perhaps, Muslims born abroad are as likely as those born in Canada to feel a very strong sense of belonging. ${ }^{44}$

The survey also reported that discrimination and stereotyping continue to be a complex reality for Muslims in Canada, particularly to women and youth. ${ }^{45}$

\section{Newly Emergent Muslim; Recently Adapted Muslimness}

The Muslim population is a mix of the newcomers and the third and fourth generations of established families. Nearly twofifths of the foreign-born Muslims in Canada arrived here during 2001-2006. It is an indication that a sizeable segment of the population is still going through the early phases of adjustment and integration, pulled, on the one hand, by the desire to preserve ethnic languages, cultures and communities and pushed, on the other hand, to adapt. This process is neither swift nor smooth. ${ }^{46}$

The Muslim population in Canada has undergone significant demographic changes. Still, from the perspective of integration into the broader society and future Muslim leadership and institutions, none is more critical than the acceleration in the pace of the compositional change. Compared with immigrants, Canadian-born Muslims differ in several ways. In one sense, they are more integrated into Canadian society (born there), which is reflected in their lack of devotion to patriarchal values. On the other hand, Muslims born in Canada are also much more concerned about how the broader society treats their community than immigrants. Compared with immigrants, they are more likely to be worried about discrimination and experience inhibition

\footnotetext{
${ }^{44}$ Ibid.

${ }^{45}$ Ibid.

${ }^{46}$ Hamdani, "Canadian Muslims."
} 
regarding political beliefs. These groups are most pessimistic about the treatment of the next generation of Muslims and are most uncomfortable with Bill C-51. ${ }^{47}$

Some scholars note how Muslim youth develop certain adaptation towards religion. As Tiflati ${ }^{48}$ suggests, his study participants successfully absorb the core values of Canadian society, such as considering the individual the authentic center of life. ${ }^{49}$ This phenomenon reiterates what Hassen ${ }^{50}$ said that a 'decultured' understanding and practice of Islam had been adopted by Muslim youth in the West. Both traditional and modern sources influence their religious identity. Further added, a version of Islam that matches their 'Westness' has been developed. They insist that by having a strong Muslim identity, they are capable of fully participating in society, culturally, socially, and politically." 51 They also consider themselves individually responsible for and capable of building their relationship with religion. ${ }^{52}$ In other words, they attribute personal and different meanings to Islam as a primary marker of their identity. ${ }^{53}$

This situation is also informed by the survey ${ }^{54}$ that youth (ages 18 to 34 years) or Muslim youth, particularly second-generation Canadians, tend to be the most religiously observant in the Muslim community. Their likely characteristics include frequent visits to mosques, wearing the hijab, and supporting the right to pray in school. These young Muslims identify primarily as Muslim, not Canadian, and feel slightly less connected to the country than older

\footnotetext{
${ }^{47}$ Environics Institute, "Survey of Muslims."

48 Hicham Tiflati, "Muslim Youth Between Quebecness and Canadianness: Religiosity, Identity, Citizenship, and Belonging," Canadian Ethnic Studies, Vol. 49, No. 1 (2017), 1-17.

49 Peter Beyer, "Growing Up Canadian: Systemic and Lived Religion," in Peter Beyer and Rubina Ramji (eds.), Growing Up Canadian: Muslims, Hindus, Buddhists (McGill-Queen's University Press, 2013), 56.

50 Yasmin Hassen, "Making Muslims: The Politics of Religious Identity Construction and Victoria's Islamic Schools," Islam and Christian-Muslim Relations, Vol. 24, No. 4 (October, 2013), 501-517.

${ }^{51}$ Beyer, "Growing Up Canadian."

52 Peter Beyer and Rubina Ramji (eds.), Growing Up Canadian: Muslims, Hindus, Buddhists (Montreal: McGill-Queen's University Press, 2013), available at $<$ http://site.ebrary.com/id/10748473>.

53 Hassen, "Making Muslims."

54 Environics Institute, "Survey of Muslims."
} 
Muslims. Moreover, they express concern over the future treatment of Muslims and report greater levels of discrimination. In contrast, Muslims aged 60 and older are among the most integrated. They identify more as Canadians than as Muslims and demonstrate the least concern about discrimination and violent extremism. ${ }^{55}$

In contrast, religious socialization of their children seems to have been highly valued by the first-generation Muslim parents. ${ }^{56}$ However, religion is seen as occasionally no longer centrally important. Tiflati ${ }^{57}$ added that strong religious socialization of Muslim children does not necessarily lead them to be religious in their adult life or to adopt their parents' religious values.

\section{Proposal for Finding a New Denomination}

In alignment with differing Muslimness among Muslim youth as abovementioned, a proposal for finding a new Islamic denomination for North America, as argued by Alibhai, ${ }^{58}$ is not an exclusive idea to follow. Based on the inspiration and courage from the individual-centric movement in American JudaismReconstructionist, Conservative, and Reform-, Alibhai suggests Muslims in North America should create their separate denomination and incorporate individual-centric and gender-equal values into its founding principles. The new denomination would place the enlightenment traditions of Islam at the center of its life and programs. The most important practical consequence of leaving the assumption within the verbal revelation of the Qur'ann is corresponding to the abandonment of the legalist conception of Islam. The new denomination would be premised on the principle that it is possible to practice Islam without the Shariah. In addition to adopting a nonlegal conception of Islam, the new denomination is expected to adopt two other core principles. The first is the strong commitment to the principle of separation of church and state or secularism at the heart of the

55 Ibid.

${ }^{56}$ Beyer, "Growing Up Canadian."

57 Tiflati, "Muslim Youth."

58 M.A. Alibhai, "The Future of Islam in North America," in Nurjehan Aziz (ed.), The Relevance of Islamic Identity in Canada: Culture, Politics, and Self (Toronto, Ontario: Mawenzi House Publishers Ltd., 2015), 152-189. 
American and Canadian government systems. The second is the new denomination's strong endorsement of science as the only reliable method of inquiry into physical reality. Further, Alibhai ${ }^{59}$ anticipates that among the core institutional components of the new denomination, mosque and chapters at college campuses to train the denomination's imam and scholars.

\section{Re-positioning Mosque as Bridge Builder: Lesson from the first Canadian mosque}

Many scholars ${ }^{60}$ have concluded that mosque is not just a house of worship since it occupies an important and authoritative position in cultural, political, and associational life of Muslims. A mosque plays a significant role in a Muslim society where it serves several functions, as an education center, a clinic, a training center, and a playground. A mosque is also a place to address local problems and to find collective solutions. As indicated by Waugh, ${ }^{61}$ a mosque is more than a building since it is the centre of an ever-expanding community of support.

In a similar pattern, taking American mosques as examples, ${ }^{62}$ demonstrated the role of mosques as agents of immigrant incorporation into mainstream American society. It is also worth

\footnotetext{
${ }^{59}$ Ibid.

60 Alean Al-Krenawi, "The Role of the Mosque and Its Relevance to Social Work," International Social Work, Vol. 59, No. 3 (May, 2016), 359-367; Ihsan Bagby, "The American Mosque in Transition: Assimilation, Acculturation and Isolation," Journal of Ethnic and Migration Studies, Vol. 35, No. 3 (March, 2009), 473-490; A Belthessazar and B. Abednego, The Mosque and Its Role in Society (Canberra: Pilcow Press, 2006); Akel Ismail Kahera, "Urban Enclaves, Muslim Identity and the Urban Mosque in America," Journal of Muslim Minority Affairs, Vol. 22, No. 2 (October, 2002), 369-380; O.B Muhammad, The Role of the Mosque (London: Al-Muhajiroon Publications, 1996); D. Owen, Ethnic Minorities in Great Britain: Settlement Patterns, University of Warwick Statistical Papers No. 1 (Coventry: Centre for Research in Ethnic Relations, 1992); Ali Wardak, "The Mosque and Social Control in Edinburgh's Muslim Community," Culture and Religion, Vol. 3, No. 2 (2002), 201-219; S. Zaimeche, Education in Islam: The Role of the Mosque (Manchester: Foundation for Science Technology and Civilization., 2002).

${ }^{61}$ Earle H. Waugh, Al Rashid Mosque: Building Canadian Muslim Communities, First Edition (Edmonton, Alberta, Canada: Gutteridge Books, an imprint of The University of Alberta Press, 2018).

${ }^{62}$ H.R. Ebaugh, "Religion and the New Immigrants," in Michele Dillon (ed.), Handbook of the Sociology of Religion (Cambridge: Cambridge University Press, 2003).
} 
noting that that mosques, along with churches and temples, have helped successive generations of immigrants and their children become American. ${ }^{63}$

Meanwhile, mosques gained more significance in establishing the Muslim community. ${ }^{64}$ Over 250 mosques, Islamic associations, and Islamic centres are active in Canada, excluding numerous prayer rooms. According to the latest opinion survey of 600 Muslim Canadians, $48 \%$ of respondents attend mosque weekly, up $7 \%$ from $2006 .{ }^{65}$

The significance of mosques raises questions about their potential role in integrating newcomers or bridging Muslim and Canadian society culturally. A study by D'Addario and CERIS ${ }^{66}$ found that the Mosque, which powerfully marked the presence of religion and culture of Ahmadi Muslims in the multicultural mosaic of Toronto, become the center of the neighbourhood of a thriving faith-based community. It has fostered a sense of social cohesion and permanence for Ahmadi Muslim newcomers in Peace Village, located in Vaughan, Ontario. In a similar report followed by recommendation, Bullock ${ }^{67}$ took an example of the first mosque in Toronto, well-known as Dunda Street mosque, which assisted Muslim immigrants in the city by providing spiritual services, which can lead in turn to better integration in the wider society. Mosques provide social association, networks, and cohesion, often leading to civic engagement that contributes to and strengthens the Canadian social fabric.

However, a warranty is also given since there is a critical concern regarding inclusion to host society, whether mosque falls

\footnotetext{
${ }^{63}$ Charles Hirschman, "The Role of Religion in the Origins and Adaptation of Immigrant Groups in the United States," International Migration Review, Vol. 38, No. 3 (February, 2006), 1206-1233.

${ }^{64} \mathrm{~K}$. Bullock, Support Mosques to Assist in Muslim Integration in Canada: Policy Brief (N.p.: The Tessellate Institute, 2010); Silvia D'Addario and CERIS, "Finding Home: Exploring Muslim Settlement in the Toronto," working paper No. 68 (Toronto, Ont.: CERIS-the Ontario Metropolis Centre, 2008), available at <http://www.deslibris.ca/ID/215142>; Waugh, Al Rashid Mosque.

${ }^{65}$ Environics Institute, "Survey of Muslims," 17.

${ }^{66}$ D'Addario and CERIS, "Finding Home."

${ }^{67}$ Bullock, Support Mosques.
} 
into what Foner and $\mathrm{Alba}^{68}$ categorizes as 'bridge or barrier' to integrate with the local community. How mosque, which represents Muslim establishment, promotes social bridging or strengthens social bonding within the community. ${ }^{69}$ suggests that mosques indeed play a significant role in the acculturation process of immigrant Muslim women in their host society.

In addition, the role of imams is undoubtedly crucial as they can be a driver behind the wheel of a mosque. Several scholars have mentioned the role of Imam in the Muslim community through his leadership, which revolves around the mosque. ${ }^{70}$ It is beyond the purpose of this article to explore much further about the role of imam; however, there is a general expectation of imam in the Western, to be a cultural broker, to facilitate the integration of Muslim into the host country. ${ }^{71}$ Previously, Ozyurt ${ }^{72}$ also contends that religious leaders within mosques whose futuristic and integrationist interpretations of Islam are more successful in building bridges between their congregants and the larger society.

${ }^{68}$ Nancy Foner and Richard Alba, "Immigrant Religion in the U.S. and Western Europe: Bridge or Barrier to Inclusion?," International Migration Review, Vol. 42, No. 2 (2008), 360-392.

${ }^{69}$ Saba Şenses Ozyurt, "Bridge Builders or Boundary Markers? The Role of the Mosque in the Acculturation Process of Immigrant Muslim Women in the United States," Journal of Muslim Minority Affairs, Vol. 30, No. 3 (September, 2010), 295-315.

${ }^{70}$ Muhammad Abuelezz, “A Survey of American Imams: Duties, Qualifications and Challenges. A Quantitative and Religious Analysis" (M.A. Thesis--The University of Georgia, 2001), available at < $\underline{\text { https://getd.libs.uga.edu/ }}$ pdfs/abuelezz muhammad 201108 ma.pdf $>$; Wahiba Abu-Ras et al., "The Imam's Role in Mental Health Promotion: A Study at 22 Mosques in New York City's Muslim Community," Journal of Muslim Mental Health, Vol. 3, No. 2 (2008), 155-176; Osman Ali et al., "The Imam's Role in Meeting the Counseling Needs of Muslim Communities in the United States," Psychiatric Services, Vol. 56, No. 2 (2005), 202-205; Ihsan Bagby, "Imams and Mosque Organization in the United States: A Study of Mosque Leadership and Organizational Structure in American Mosques," in Muslims in the United States (Washington D.C.: Woodrow Wilson International Center for Scholars, 2003); Mahazan A.M. and Abdullah A.G., "A Model of Imam's Leadership and Mosque Performance in Malaysia," Global Journal Al-Thaqafah, Vol. 3, No. 2 (2013), 53-64.

${ }^{71}$ Jan Jaap De Ruiter et al., Imams in Western Europe (Amsterdam: Amsterdam University Press, 2018), available at <https://www.degruyter.com/ doi/book/10.1515/9789048540006 >.

72 Ozyurt, "Bridge Builders." 
They can also empower women congregants and facilitate their cultural and psychological adaptation within their host society.

Here, it is noteworthy to remember the experience of the first mosque built in Canada, which provides lessons of how synthesizing two cultural fabrics into a convergent of Canadianness and Muslimness. As early as the 1930s, Muslims in Canada made up 645, with the most significant concentrations in Manitoba, Saskatchewan, and Alberta. Edmonton had the most prominent Muslim community, which was increasingly concerned with passing their faith and traditions to their children. In May 1938, a small plot of land was bought for $\$ 5000$ as the site for the first Muslim place of worship in Canada. In November of that same year, Al Rashid Mosque hosted its first religious event-a funeral for Ali Tarrabain, a Muslim pioneer who immigrated to Canada at the turn of the century. December 12, 1938, was the official opening date for $\mathrm{Al}$ Rashid Mosque. It was attended by the mayor of Edmonton and the mayor of Hanna. Among notable attendants was Abdullah Yusuf Ali, a prominent Muslim scholar and Qur'ān translator, who performed the dedication. ${ }^{73}$

Despite Muslims encountered isolation and struggled for social acceptance by the host society in the early $20^{\text {th }}$ century, these early settlers wasted little time taking steps to anchor their future generations in the new homeland. Like other immigrant communities, they set up institutions to transmit their fundamental values and ease their children's transition to mainstream Canadian society. In 1938, the first mosque was built. True to the builders' vision, it blended with the local landscape instead of standing out. Resembling an Eastern Orthodox Church as much as a Middle Eastern mosque, it synthesizes the two major religious traditions, which leaves passers-by wondering about its identity. Preserved as an icon of Canada's Muslim heritage in Fort Edmonton Park, the country's largest living history museum, it receives, as it did during its active life, worshippers and tourists alike, with an enduring solemn grace. Built by the Sunni and Shia immigrants on the land donated by the people of Edmonton and financed by contributions from donors of all faiths, the opening ceremony of

${ }^{73}$ Dayrit and Milo, “A New Life.” 
the mosque was as unconventional yet solemn and spiritual as its architectural design. $^{74}$

Al-Rashid was unlike many of today's mosques. It was open to the people of all faiths, sects and genders. ${ }^{75}$ It introduced Muslim newcomers to their adopted country and helped the nation understand them. The community gathered here to celebrate weddings, hold tea parties and cultural events and invited friends, neighbours and colleagues of all faiths to join them. It bustled with activity. It was a school that smoothed the transition of young Muslims to mainstream society; a university where adults learned about Islam's universal values; a gathering place where young men and women met their future life partners; a town hall where social and political issues were raised and discussed; and a chamber of commerce where business information was exchanged and deals made. Al-Rashid transformed a voyageur into a strong community whose influence extended far beyond their small numbers and whose descendants have produced prominent personalities in Canadian public life. ${ }^{76}$

Historically, Al Rashid quickly became central to Edmonton. In the early days of the mosque's life, it became integrated into the community positively, with none of the apparent secrecy and isolation that accompanies many mosque projects today. Edmonton welcomed the mosque as indicative of the city's sophistication. The public embraced it as the home of a friendly group of people who shared their cultural lives in a lively Canadian way. People of all religious commitments - and nonecontributed to the mosque community through social events it hosted. It is a remarkable achievement that Muslims should be proud and notably a part of this Canadian urban environment. ${ }^{77}$ The early pioneers had embraced a flexible Islam and had deliberately blurred the lines of doctrine and cultural difference. ${ }^{78}$

\footnotetext{
${ }^{74}$ Hamdani, "Canadian Muslims," 3.

75 Waugh, Al Rashid Mosque.

${ }^{76}$ Hamdani, "Canadian Muslims," 3-4.

77 Waugh, Al Rashid Mosque, 88.

${ }^{78}$ Ibid., 97.
} 


\section{Conclusion}

To maintain multiculturalism to flourish, Canada should be settling upon the differences and embracing the diversity of its population irrespective of their ethnicity, race, religion, gender, and any type. However, a reliable mechanism to filter and infiltrate those values fully compatible with Canadian values must be taken seriously. By taking the lesson from the first mosque built in Canada, Muslim congregation and other Islamic establishments currently participating in this project find general and universal values found within Islamic texts that will be embraced and infused into Canadian society.

It is not an overstatement to expect that shortly the Muslim community can live in peace and harmony without being occupied with the burden of Canadian values or being hesitant to absorb Canadianness. Finding the same patterns, seeking commonality, and strive for universal values found within Canadian dan Islam are inexorably quest for emerging Islam Canada.

The emergence of Canadian Muslim youth, which may breed a new hybrid culture, must be well anticipated. The mixed culture of these newly emergent Muslim communities could be an unavoidable fact that must be taken diligently to preserve the mosaic of multiculturalism, which has become an inseparable parcel of Canada's identity. Collaborative work to support the incorporation of this hybrid culture can be established. Imagining Canadian Muslim identity for youth, especially those categorized under Generation Y and Z, will be another avenue to instill a new model of hybrid, which requires endless effort to promote and maintain harmony in diversity. Here it is essential to clearly distinguish Islam as a set of religious values or a conflation of ethnic or tribal values which distort the real essence of Islamic values. Analogically speaking, the essence of Islam is like a fire, and the practices attributed to or even considered part of Islam are ashes. So, it is crucial to identify whether a practice is genuinely fire or just ashes.

Islam is not a monolithic religion, and multi interpretations are available. Therefore, open discussion is a must to find out the essence of Islam. Here leadership centred around Muslim establishment such as mosques to manage this situation is urgently 
required. The next challenge is to find any leadership which able to perform this reformation project.

This article attempts to establish an argument that the Muslim community exists within the scope of a historically specific, rather than homogenous and static form, with attention to discourses of othering and exclusion. This article also demonstrates that there are multifaceted forms of performing Islam and Muslimness that need to be brought to light and examined. Situating knowledge about marginalized and under-researched subjects, this study will spark a conversation that Muslimness and Canadianness as contested identities are often produced and reproduced concerning the dominant and hegemonic power dynamics of mainstream Islam in Canada.

\section{Bibliography}

Abuelezz, Muhammad. "A Survey of American Imams: Duties, Qualifications and Challenges. A Quantitative and Religious Analysis." M.A. Thesis--The University of Georgia, 2001), available at <https://getd.libs.uga.edu/pdfs/abuelezz muh ammad 201108 ma.pdf $>$.

Abu-Ras, Wahiba et al. 'The Imam's Role in Mental Health Promotion: A Study at 22 Mosques in New York City's Muslim Community," Journal of Muslim Mental Health, Vol. 3, No. 2, 2008.

Adams, Michael. "Muslims and Multiculturalism in Canada," 2007, available at <http://www.environicsinstitute.org/PDFMuslimsandMulticulturalisminCanada-LiftingtheVeil.pdf $>$.

Ali, Osman et al. "The Imam's Role in Meeting the Counseling Needs of Muslim Communities in the United States," Psychiatric Services, Vol. 56, No. 2, 2005.

Alibhai, M.A. "The Future of Islam in North America," in Nurjehan Aziz (ed.), The Relevance of Islamic Identity in Canada: Culture, Politics, and Self. Toronto, Ontario: Mawenzi House Publishers Ltd., 2015.

Allen, Kelly-Ann. The Psychology of Belonging, First Edition. N.p.: Routledge, 2020.

Bagby, Ihsan. "Imams and Mosque Organization in the United States: A Study of Mosque Leadership and Organizational Structure in American Mosques," in Muslims in the United 
States. Washington D.C.: Woodrow Wilson International Center for Scholars, 2003.

-----. "The American Mosque in Transition: Assimilation, Acculturation and Isolation," Journal of Ethnic and Migration Studies, Vol. 35, No. 3, March, 2009.

Baumeister, Roy F. and Mark R. Leary. "The Need to Belong: Desire for Interpersonal Attachments as a Fundamental Human Motivation," Psychological Bulletin, Vol. 117, No. 3, 1995.

Belthessazar, A. and B. Abednego. The Mosque and Its Role in Society. Canberra: Pilcow Press, 2006.

Beyer, Peter and Rubina Ramji (eds.). Growing Up Canadian: Muslims, Hindus, Buddhists. Montreal: McGill-Queen's University Press, 2013, available at <http://site.ebrary. com/id/10748473>.

Beyer, Peter. "Growing Up Canadian: Systemic and Lived Religion," in Peter Beyer and Rubina Ramji (eds.), Growing Up Canadian: Muslims, Hindus, Buddhists. McGill-Queen's University Press, 2013.

Bullock, K. Support Mosques to Assist in Muslim Integration in Canada: Policy Brief. N.p.: The Tessellate Institute, 2010.

CJPME. "2018 Survey: Islamophobia in Canada, Still A Grace Problem," 2018, available at <https://www.cjpme.org/ islamophobia >; Azeezah Kanji, "Islamophobia in Canada: Submission to the UN Special Rapporteur on Freedom of Religion or Belief," November 30, 2020, available at $<$ https://www.ohchr.org/Documents/Issues/Religion/Islam ophobia-AntiMuslim/Civil $\% 20$ Society $\% 20$ or $\% 20$ Individuals/ Noor-ICLMG-ISSA.pdf $>$.

Clyne, Michael and James Jupp. Multiculturalism and Integration (N.p.: ANU Press, 2011), available at <http://www. jstor.org/stable/j.ctt24h7j6> accessed on May 6, 2021.

Cockshaw, Wendell David and Ian Shochet. "The Link between Belongingness and Depressive Symptoms: An Exploration in the Workplace Interpersonal Context," Australian Psychologist, Vol. 45, No. 4, December, 2010.

D'Addario, Silvia and CERIS. "Finding Home: Exploring Muslim Settlement in the Toronto," working paper No. 68. Toronto, 
Ont.: CERIS-the Ontario Metropolis Centre, 2008, available at $<$ http://www.deslibris.ca/ID/215142> .

D'Haenens, Leen. Images of Canadianness: Visions on Canada's Politics, Culture, and Economics. N.p.: University of Ottawa Press, 1998.

Dayrit, Flordeliza and Michael Milo. "A New Life in a New Land: The Muslim Experience in Canada," 2015, available at $<$ https://www.anewlife.ca/ $>$.

Ebaugh, H.R. "Religion and the New Immigrants," in Michele Dillon (ed.), Handbook of the Sociology of Religion. Cambridge: Cambridge University Press, 2003.

Environics Institute. "Survey of Muslims in Canada 2016: Final Report," April 30, 2016, available at $<$ http://www.environicsinstitute.org/uploads/institute-projec ts $/$ survey $\% 20$ of $\% 20$ muslims $\% 20$ in $\% 20$ canada $\% 202016 \% 20$ $\% 20$ final $\% 2$ 0report.pdf $>$.

Erin, G.M.D. "Muslims in Canada: Collective Identities, Attitudes of Otherment and Canadian Muslim Perspectives on Radicalism," Islamophobia Studies Journal, Vol. 3, No. 1, 2015.

Foner, Nancy and Richard Alba. "Immigrant Religion in the U.S. and Western Europe: Bridge or Barrier to Inclusion?," International Migration Review, Vol. 42, No. 2, 2008.

Haghbin, Reihaneh. "The Problem of Muslimness: Reconsidering the Theology of Inclusion-Exclusion in Muslim Thought." N.p.: Middlesex University, 2016, available at $<$ https://www.islamic-college.ac.uk/wp-content/uploads/20 18/10/Reihaneh-HAGHBIN-Dissertation-final.pdf $>$.

Hamdani, Daood. "Canadian Muslims: A Statistical Review," The Canadian Dawn Foundation, 2015, available at $<$ https://muslimlink.ca/pdf/Canadian-Muslims-A-StatisticalReview-Final.pdf $>$.

Hassen, Yasmin. "Making Muslims: The Politics of Religious Identity Construction and Victoria's Islamic Schools," Islam and Christian-Muslim Relations, Vol. 24, No. 4, October, 2013.

Helie, Anissa. "Introduction: Policing Gender, Sexuality and 'Muslimness,"' in Sexuality in Muslim Contexts-Restrictions and Resistance. N.p.: Zed Books, 2012.

Hirschman, Charles. "The Role of Religion in the Origins and Adaptation of Immigrant Groups in the United States," International Migration Review, Vol. 38, No. 3, February, 2006. 
Hopkins, Vered Kahani and Nick Hopkins. "'Representing' British

Muslims: The Strategic Dimension to Identity Construction," Ethnic and Racial Studies, Vol. 25, No. 2, January, 2002.

Houtsma, M. Th (ed.). E.J. Brill's First Encyclopaedia of Islam, 19131936. Leiden; New York: E.J. Brill, 1987.

Kahera, Akel Ismail. "Urban Enclaves, Muslim Identity and the Urban Mosque in America," Journal of Muslim Minority Affairs, Vol. 22, No. 2, October, 2002.

Kawser, Ahmed. "Radicalism Leading to Violent Extremism in Canada: A Multilevel Analysis of Muslim Community and University Based Student Leaders' Perceptions and Experiences," Journal for Deradicalization, No. 6, 2016.

Krenawi (al), Alean. "The Role of the Mosque and Its Relevance to Social Work," International Social Work, Vol. 59, No. 3, May, 2016.

Kymlicka, Will. "Being Canadian," Government and Opposition, Vol. 38, No. 3, 2003.

Lucas, M. Hélie. “What Is Your Tribe? Women's Struggles and the Construction of Muslimness," in Annisa Helie and Homa Hoodfar (eds.), Women Living Under Muslim Laws. London; New York: Zed Books, 2004.

Magocsi, Paul R. (ed.). Encyclopedia of Canada's Peoples. Toronto; Buffalo: University of Toronto Press, 1999.

Maslow, Abraham H. Toward a Psychology of Being, Second Edition, New York: D. Van Nostrand Company, 1968.

Muhammad, O.B. The Role of the Mosque. London: Al-Muhajiroon Publications, 1996.

Mutalib, Mahazan A. and A.G. Abdullah. "A Model of Imam's Leadership and Mosque Performance in Malaysia," Global Journal Al-Thaqafah, Vol. 3, No. 2, 2013.

Nayel, Amina Alrasheed. Alternative Performativity of Muslimness. Cham: Springer International Publishing, 2017, available at $<$ http://link.springer.com/10.1007/978-3-319-44051-4> accessed on April 16, 2021.

Nemetz, Patricia L. and Sandra L. Christensen. "The Challenge of Cultural Diversity: Harnessing a Diversity of Views to Understand Multiculturalism," The Academy of Management Review, Vol. 21, No. 2, April, 1996. 
O’Brien, Kelly K. et al. “Advancing Scoping Study Methodology: A Web-Based Survey and Consultation of Perceptions on Terminology, Definition and Methodological Steps," BMC Health Services Research, Vol. 16, No. 1, December, 2016.

Owen, D. Ethnic Minorities in Great Britain: Settlement Patterns, University of Warwick Statistical Papers No. 1. Coventry: Centre for Research in Ethnic Relations, 1992.

Ozyurt, Saba Şenses. "Bridge Builders or Boundary Markers? The Role of the Mosque in the Acculturation Process of Immigrant Muslim Women in the United States," Journal of Muslim Minority Affairs, Vol. 30, No. 3, September, 2010.

Peterson, Jessica et al. "Understanding Scoping Reviews: Definition, Purpose, and Process," Journal of the American Association of Nurse Practitioners, Vol. 29, No. 1, January, 2017.

Qazzaz (al), Khaled. "Islamophobia Is on the Rise during COVID-

19," Policy Options, October 2020, availabe at $<$ https://policyoptions.irpp.org/magazines/october-2020/isl amophobia-is-on-the-rise-during-covid-19/>.

Ruiter, Jan Jaap De et al. Imams in Western Europe. Amsterdam: Amsterdam University Press, 2018, available at $<$ https://www.degruyter.com/doi/book/10.1515/978904854 $\underline{0006}>$.

Selby, Jennifer A. “'Muslimness' and Multiplicity in Qualitative Research and in Government Reports in Canada," Critical Research on Religion, Vol. 4, No. 1, April 2016.

Statistics Canada. "2011 National Household Survey ProfileCensus Metropolitan Area/Census Agglomeration," May 8, 2011, available at <https://www12.statcan.gc.ca/nhsenm/2011/dppd/prof/details/page.cfm?Lang $=E \& G e o 1=C$

MA\&Code1 $=462 \&$ Data $=$ Count $\&$ Search $T e x t=$ montreal $\&$ Sear ch Type $=$ Begins $\&$ SearchPR $=01 \& A 1=$ Religion $\& B 1=$ All\&Cust $\mathrm{om}=\& \mathrm{TABID}=1>$

Steger, Michael F. and Todd B. Kashdan. "Depression and Everyday Social Activity, Belonging, and Well-Being," Journal of Counseling Psychology, Vol. 56, No. 2, 2009.

Studin, Irvin. "What Is a Canadian?: Forty-Three ThoughtProvoking Responses." Toronto: M \& S, 2006, available at $<$ http://catdir.loc.gov/catdir/enhancements/fy0624/200649 4464-s.html $>$. 
Sulaiman, Mohammed. "Muslimness as a Political Formation: An Inquiry into Muslim Presence," Social Identities, Vol. 26, No. 1, January, 2020.

Tiflati, Hicham. "Muslim Youth Between Quebecness and Canadianness: Religiosity, Identity, Citizenship, and Belonging," Canadian Ethnic Studies, Vol. 49, No. 1, 2017.

Wardak, Ali. "The Mosque and Social Control in Edinburgh's Muslim Community," Culture and Religion, Vol. 3, No. 2, 2002.

Waugh, Earle H. Al Rashid Mosque: Building Canadian Muslim Communities, First Edition. Edmonton, Alberta, Canada: Gutteridge Books, an imprint of The University of Alberta Press, 2018.

Wences, Isabel. "Quebec Interculturalism: A Version of Canadian Multiculturalism or a Model with an Institutional Structure?," Convergencia, Vol. 23, No. 72, 2016.

Wohlin, C. "Guidelines for Snowballing in Systematic Literature Studies and a Replication in Software Engineering," in Proceedings of the 18th International Conference on Evaluation and Assessment in Software Engineering, Vol. 38, Citeseer, 2014.

Zaimeche, S. Education in Islam: The Role of the Mosque. Manchester: Foundation for Science Technology and Civilization, 2002. 